\title{
Myxidium mackiei (Myxosporea) in Indo-Gangetic flap-shelled turtles Lissemys punctata andersonii: parasite-host interaction and ultrastructure
}

\author{
K. L. Helke ${ }^{1,2, *}$, S. L. Poynton ${ }^{1}$ \\ ${ }^{1}$ Department of Comparative Medicine, and ${ }^{2}$ Department of Pathology, The Johns Hopkins University School of Medicine, \\ Broadway Research Building, Rm 863, 733 North Broadway Street, Baltimore, Maryland 21205-2196, USA
}

\begin{abstract}
Myxosporeans are common parasites of fish, and uncommon parasites of amphibians, reptiles and invertebrates, that can cause significant morbidity and mortality. The common genus Myxidium infects the excretory system of turtles, yet knowledge of its pathogenicity in these hosts is limited. We offer new knowledge of morphological and ultrastructural aspects of host-parasite interactions in Myxidium infections from our recent diagnostic investigations on captive freshwater turtles listed in CITES (Appendix II). We investigated the cause of death of 2 adult Indo-Gangetic flapshelled turtles Lissemys punctata andersonii from a zoo collection. After post-mortem examination, tissues were processed for histopathology, and special stains were used to demonstrate morphology of myxosporean spores. Additional kidney tissue, immersion-fixed in formalin, was processed for transmission electron microscopy. Both turtles were infected with a myxosporidian, Myxidium mackiei, in the kidney, which occluded 5 to $10 \%$ of the renal proximal convoluted tubules. The polysporic plasmodia contained pairs of developing and mature spores. Each mature, spindle-shaped spore had 2 asymmetric valves (1 overlapping, 1 overlapped), with 10 to 13 and 10 to 14 longitudinal ridges per valve, and 2 polar capsules each containing a polar filament with 4 to 5 turns. A pair of spores, each surrounded by a membrane-bound electron-lucent matrix, lay in an enclosing cell within the plasmodium. Regions of the parasite-host interface consisted of undulations of the parasite surface, with intense pinocytotic activity beneath, intermingled with the hosts' microvilli, and endocytotic channels at the apex of renal epithelial cells. The microvilli of the renal epithelial cells of infected tubules were frequently sheared or compressed, or occasionally missing; we did not detect other pathology induced by the parasite. Our report of M. mackiei in L. punctata is a new host record. Both individuals also had disseminated pale yellow nodules (bacterial granulomas) present in lung, heart, kidney, and skeletal muscle, and both were infected with coccidia (tentatively identified as Eimeria sp.) in multiple organs. The cause of death for one turtle was septicemia, but remained unknown for the other individual.
\end{abstract}

KEY WORDS: Myxosporea · Turtle $\cdot$ Kidney $\cdot$ Ultrastructure

\section{INTRODUCTION}

Myxosporeans are common parasites of cavities and tissues of fish, and uncommon parasites of amphibians, reptiles, and invertebrates (Lom \& Dyková 1992). They have attracted particular attention because of their unique structure (multicellular spores with nematocyst-like polar capsules), life cycle (which may involve myxosporean spores in vertebrate hosts, and actinosporean stages in invertebrate hosts), and pathogenicity (both presporogonic developmental stages and spores cause significant morbidity and mortality in commercially important fish) (Lom \& Dyková 1995).

The urinary excretory system is a site of infection for 5 myxosporean genera (Myxidium, Ortholinea, Sinulinea, Sphaerospora, and Zschokkella), with infections 
localized in the renal tubules, renal corpuscles, and urinary bladder (Dyková et al. 1987). Of these, only Myxidium has been reported from the urinary excretory system of turtles (Bosanquet 1910, Kudo 1919, Johnson 1969a,b), and the reports from North America, France, and India comprise morphology and host-parasite records. Although Myxidium is one of the most common myxosporean genera, with at least 116 reported species (Dyková et al. 1987), knowledge of the pathogenicity is very limited (Jayasari \& Hoffman 1982).

The Indo-Gangetic flap-shelled turtle Lissemys punctata andersonii (Trionychidae) is listed in Appendix II of CITES (i.e. is a species that is not necessarily now threatened with extinction but may become so) (www.cites.org). Investigation of the cause of death of specimens from India or Pakistan, held in a zoo in the USA, gave us the opportunity to examine Myxidium infection in the renal tubules. We describe the morphology of the parasite in histological section, ultrastructure of the plasmodia and spores contained therein, and the relationship with the host. We also describe the ultrastructure of the renal tubules of the turtles, which shares structural similarities with that of fish. At necropsy, other significant findings included disseminated bacterial granulomas and coccidiosis.

\section{MATERIALS AND METHODS}

Case histories. Two adult female Indo-Gangetic flap-shelled turtles of unknown age were submitted for post-mortem examination 6 and 7 mo after acquisition in 2001. Both freshwater turtles were wild-caught in India or Pakistan, and were obtained by the zoo from a dealer in May 2001. Case 1 (1.35 kg) was found dead in its enclosure after previously being noted to be healthy. Case $2(1.10 \mathrm{~kg})$ had a 2 mo history of lethargy, dyspnea, and edema and had been treated with furosemide, antibiotics, and steroids prior to death. Both cases had received numerous doses of metronidazole and levamisole to treat heavy parasite burdens. The first specimen was in poor condition upon arrival for the post-mortem, due to dying overnight in a hot enclosure. The second specimen was in good condition at post-mortem, having been refrigerated for the $8 \mathrm{~h}$ between death and necropsy.

Gross and histological examination. Post-mortem examinations were done on both individuals and samples of heart, skeletal muscle, lung, liver, spleen, gastrointestinal (GI) tract, kidney, and nodules found throughout the coelom, musculature and viscera were fixed in $10 \%$ neutral buffered formalin (NBF) and processed for paraffin embedding. Sections of approximately $5 \mu \mathrm{m}$ thickness were cut, placed on negatively charged glass slides, and stained with hematoxylin and eosin (H\&E).
A Gram stain was also used to better visualize the bacteria within the nodules. We also used the Prussian blue stain to test for iron, Hall's bilirubin stain to test for bile, and Periodic-Acid Schiff (PAS) to test for lipofuscin in the globules (appearing golden in hematoxylin and eosin H\&E) identified within the renal interstitium and within the plasmodia.

To visualize morphology of myxosporean spores in kidney tubules, additional sections of kidney were stained with Giemsa, Gomori-methenamine silver (GMS), Periodic acid Schiff (PAS), and Ziehl-Neelsen acid-fast (Gardiner et al. 1988). Measurements of spores were taken following the recommendations of Lom \& Arthur (1988), using an ocular micrometer in a Nikon E400 light microscope.

Electron microscopy. To investigate the ultrastructure of the myxosporidian and host-parasite interface, kidney tissues from Case 2 were retrieved from $10 \%$ neutral buffered formalin (NBF) and processed for transmission electron microscopy. Formalin-fixed tissues were post-fixed in glutaraldehyde and paraformaldehyde and $0.05 \mathrm{M}$ sodium cacodylate buffer with $3 \mathrm{mM} \mathrm{CaCl}_{2}$ at $\mathrm{pH}$ 7.4. Tissues were embedded in Epon resin and sectioned on a Reichert-Jung Ultracut E microtome, utilizing a low angle Diatome diamond knife. Semi-thin sections $0.5 \mu \mathrm{m}$ thick were stained with toluidine blue and examined for the presence of infected tubules. Subsequently, 70 to $80 \mathrm{~nm}$ thin sections were collected on Formvar-coated $1 \times 2 \mathrm{~mm}$ copper slot grids (Pella), and stained with uranyl acetate and then lead citrate. All grids were viewed and photographed on a Phillips CM 120 TEM operating at $80 \mathrm{kV}$.

\section{RESULTS}

\section{Gross pathology}

In Case 1, an autolyzed specimen, multiple pale yellow firm nodules, solid and dry on cut surface and 0.1 to $0.4 \mathrm{~cm}$ in diameter, were present throughout the skeletal muscle, lungs, kidney, and heart. On the heart, the nodules were attached to the epicardial surface, and the ventricles were lined with similar pale yellow material.

In Case 2, pale yellow nodules 0.5 to $4 \mathrm{~cm}$ in diameter, with a caseous consistency when cut, were free within the coelom. The soft tissues were edematous, and the lungs were mottled red and pink.

\section{Histopathology}

In both cases, the yellow nodules were found to be granulomas laden with Gram-positive rods and cocci, and Gram-negative rods. The granulomas consisted of 


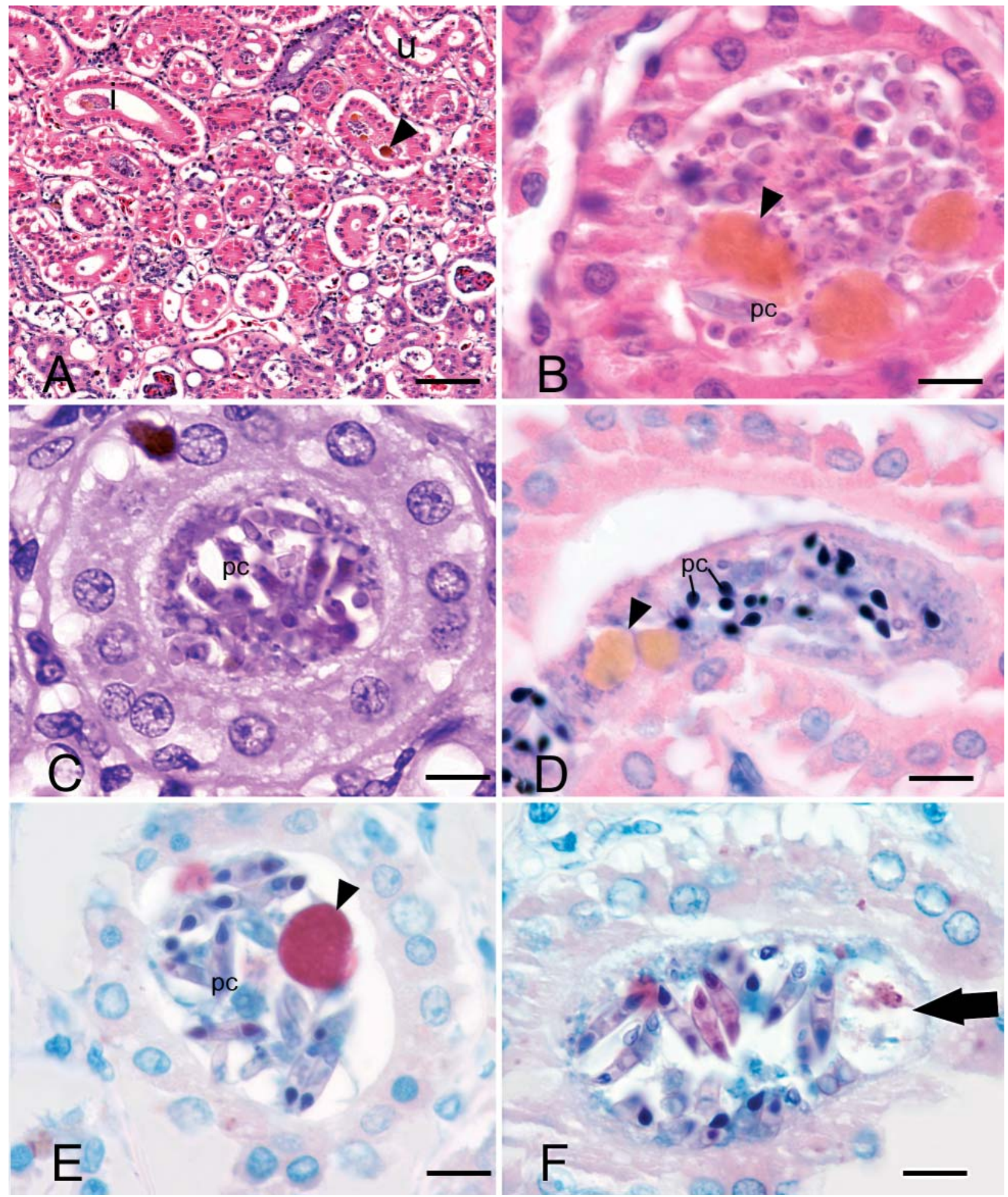

Fig. 1. Histological sections of Myxidium mackiei spores within plasmodia in the renal proximal convoluted tubules of the turtle Lissemys punctata andersonii. (A) Overview showing infected (i) and uninfected (u) tubules with golden pigment globules (arrowhead); hematoxylin and eosin (H\&E). (B) Tubule containing plasmodium; note golden globules (arrowhead) within tubule, polar capsule (pc); H\&E. (C) Spores within plasmodium in renal tubule, polar capsule (pc); periodic acid-Schiff (PAS). (D) Distinct dark blue polar capsules (pc); Giemsa. (E) The spores and polar capsules (pc) stain different colors dependent upon maturation stage; the globules (arrowhead) stain pink; Ziehl-Neelsen acid-fast. (F) Concurrent infection with both M. mackiei and Eimeria (arrow); Ziehl-Neelsen acid-fast. Scale bars: $(A)=100 \mu \mathrm{m} ;(B-F)=10 \mu \mathrm{m}$ 


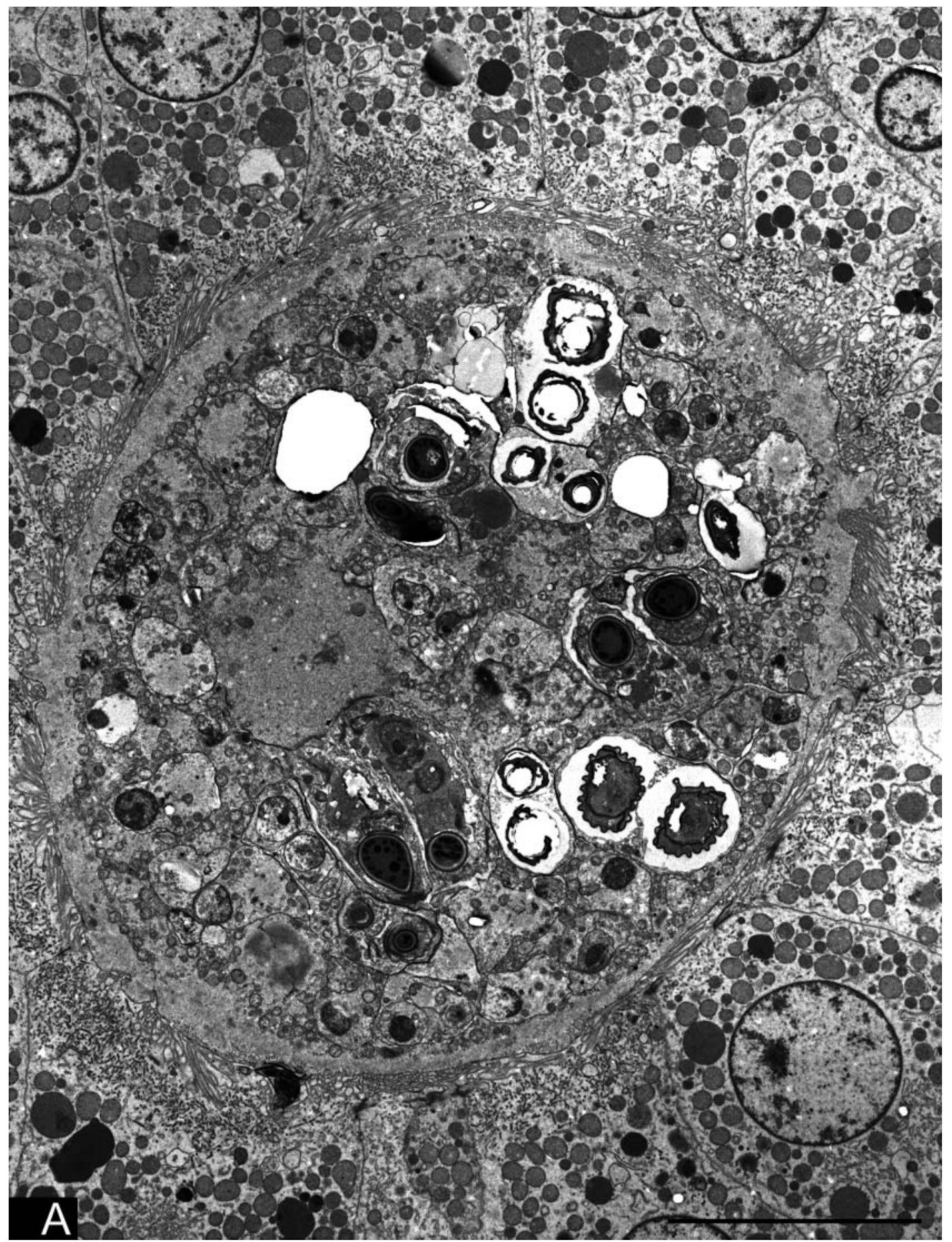

Fig. 2. (Above and facing page.) Transmission electron micrograph of plasmodium of Myxidium mackiei in a renal proximal convoluted tubule of the turtle Lissemys punctata andersonii. (A) Non-annotated figure. (B) Annotated figure with different stages of sporogenesis indicated by different colors. The plasmodium has a finely granular ectoplasm (ec) with regions of pinocytosis (pi), and a complex heterogeneous endoplasm (en) containing vegetative nuclei (vn), numerous spherical mitochondria (mi), an inclusion of relatively homogenous cytoplasm (ci) and cell complexes representing sequential stages of sporogony: cell triplets (yellow) (ct) with an outer amoeboid cell, enclosing 2 inner cells with nuclei (n); developing spores (red) (ds); and mature spores (green-dashed) (ms) lying in pairs in an electron-lucent matrix, within a finely granular matrix, note distinctive 'cog-wheels within a figure 8' appearance in transverse section. The place in the developmental sequence was uncertain for some cell complexes (blue). In some cases, the outline of membranes could not be completely traced; in such cases lines are not entire. Note that the host's microvilli $(\mathrm{mvc})$ are compressed by the parasite. Scale bar $=10 \mu \mathrm{m}$ 


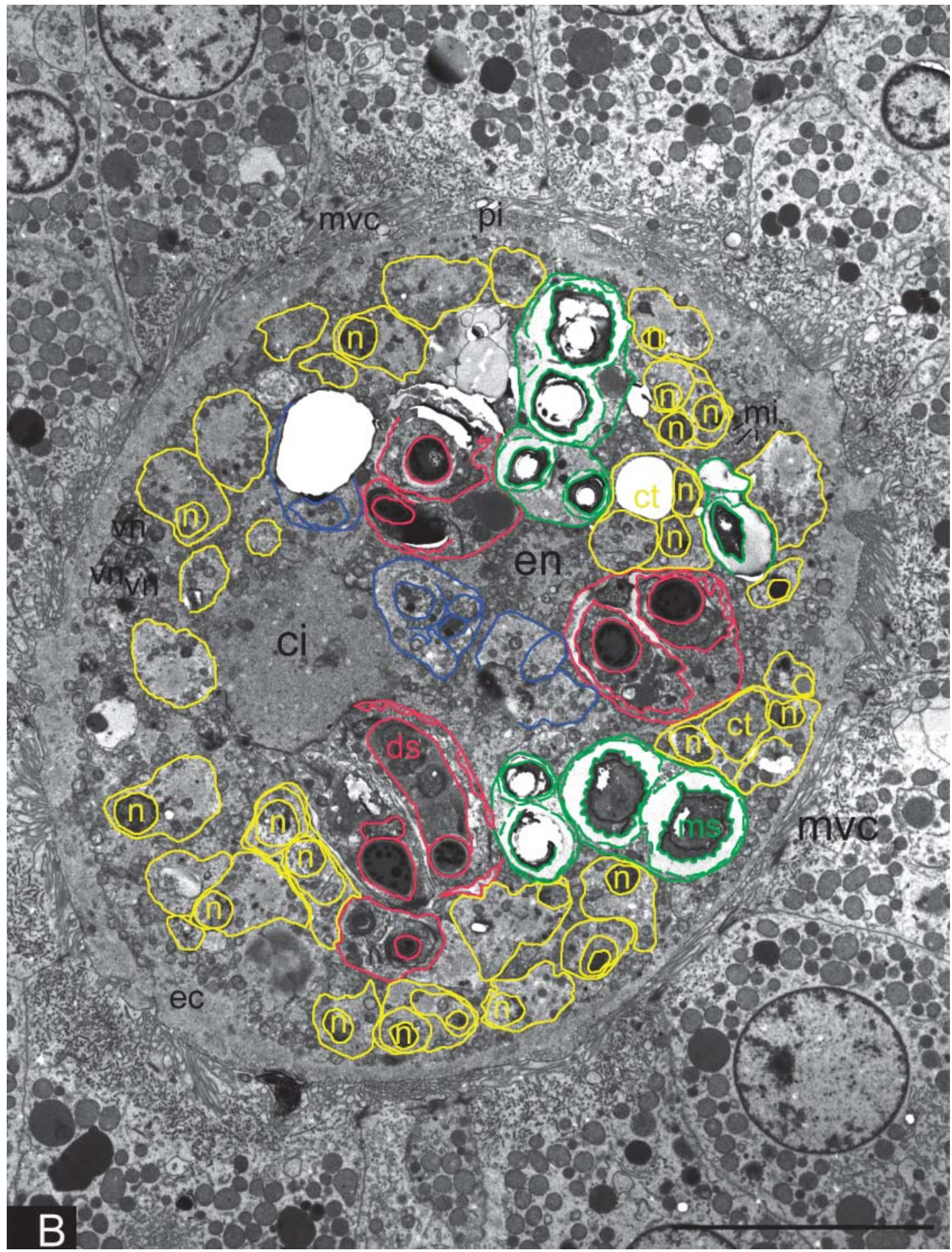

Fig. 2 (continued)

a core of amorphous cellular debris surrounded by multinucleate histiocytes, and only in a few instances was fibrosis present surrounding the lesion.

In Case 1, granulomatous myositis, pyogranulomatous pancarditis, granulomatous pneumonia, cholangiohepatitis, tubular mineralization of the kidney, serous atrophy of the adipose tissue, and granulomatous adenitis of the adrenal gland were present. There were several sites where bacteria could be seen within the vessels, indicating a septicemia, which was likely the cause of death for this individual. Approximately $5 \%$ of the proximal convoluted tubules of the 
kidney contained plasmodia with spores of the myxosporidian parasite Myxidium mackiei (see below). Multiple globules of golden pigment (visualized in $\mathrm{H} \& \mathrm{E})$, up to $50 \mu \mathrm{m}$ in diameter were present within the plasmodium (Fig. 1A), and within the interstitium of the kidney. In the nasal mucosa, Eustacian tube, pharynx, lung and liver, sporulated coccidian oocysts, tentatively identified as Eimeria sp., were also present (authors' unpubl. data). The eimerian had thin-walled oocysts, which were approximately spherical, and contained 4 ovoid sporocysts, each of which contained 2 club-shaped sporozoites arranged head to tail; morphology is consistent with Eimeria according to Perkins et al. (2000).

In Case 2, there was granulomatous myocarditis, granulomatous pneumonia, and interstitial granulomatous nephritis (that was separate and not related to the $M y x-$ idium infection). Multifocal myositis, multifocal granulomatous hepatitis with associated coccidia, and diffuse enteritis were also present. Cause of death was not determined despite thorough examination of all tissues in section; death due to the profound bacterial infection was not ruled out. Approximately $10 \%$ of the proximal convoluted tubules of the kidney contained plasmodia with spores of M. mackiei. Multiple globules of golden pigment (visualized in $\mathrm{H} \& \mathrm{E}$ ), up to $50 \mu \mathrm{m}$ in diameter were present within the plasmodium (Fig. 1A), and within the interstitium of the kidney. In the kidney, lung, liver, small intestine, submucosa of the oral cavity and nasal cavity were sporulated coccidian oocysts indistinguishable from those in Case 1, and therefore also tentatively identified as Eimeria sp. (Fig. 1F).

No other parasites were seen in either individual, thus we were not able to correlate our histopathological findings with the treatment of these 2 individuals for flagellate and helminth infections with metronidazole and levamisole respectively (see case histories).

\section{Myxidium mackiei: morphology (in histologic section)}

In general, a single plasmodium was present in each cross section of tubule, containing up to 25 Myxidium mackiei spores; in some cases the plasmodium completely occluded the tubules (Fig. 1). In 1 tubule, 2 separate plasmodia, each filled with spores at various stages of maturity, were seen.

Spores were straight and spindle-shaped in longitudinal section, 12.9 to $17.6 \mu \mathrm{m}$ long and 2.9 to $4.7 \mu \mathrm{m}$ wide with pointed ends $(\mathrm{n}=10)$, and arranged side by side in pairs (Fig. 1B-F). Longitudinal striations were not discerned with any of the stains used in this study. Opposite, pyriform, polar capsules were 3.4 to $4.1 \mu \mathrm{m}$ long and 2.1 to $2.4 \mu \mathrm{m}$ wide $(\mathrm{n}=10)$. The polar capsules were in- distinct in H\&E, but clearly stained with Giemsa, GMS, PAS, and Ziehl-Neelsen acid-fast (Fig. 1B-F).

With the Ziehl-Neelsen acid-fast stain, a dark staining, refractile, coiled polar filament, with 4 to 5 turns, could be discerned within each polar capsule. A circular to crescentic capsulogenic nucleus was present at the base of each polar capsule (Fig. 1E) (which also stained with the Giemsa stain), and 2 larger circular sporoplasmic nuclei lay along the longitudinal axis in the middle of the spore. Two vacuoles could sometimes be seen, each lying along the longitudinal axis of the spore, between a capsulogenic and sporoplasmic nucleus. With the ZiehlNeelsen acid-fast stain, the golden globules within the plasmodia and renal interstitium stained magenta. The globules did not autofluoresce (Fig. 1E).

The renal tubular epithelium did not appear to be affected by the parasite when viewed by light microscopy. The epithelial cells were separating from the basement membrane in some histological sections, but this appeared to be artifactual, since in the transmission electron micrographs, the renal tubular epithelial cells appeared to be in full contact with the basement membrane.

\section{Myxidium mackiei: ultrastructure of the plasmodium}

Polysporic plasmodia, most of which contained developing and/or mature spores, occluded the lumen of infected tubules (Fig. 2). The large plasmodia were recognized as the vegetative stages of the myxosporean (the trophozoite stage). Adjacent to the parasite, the microvilli of the renal epithelial cells were frequently sheared or compressed, or were effaced from part or all of the luminal surface (Figs. 2 to 4 ).

The appearance of the plasmalemma varied considerably within a single plasmodium, and between different plasmodia. The simplest regions were lobes that invaginated into the apical portion of the cell, and had no host microvilli around them, and no pinocytotic activity beneath (Fig. 3A). The most complex regions of the parasite-host interface consisted of intermingled undulations of the parasite surface (subtended by areas of intense pinocytotic activity), sheared and compressed host microvilli, and endocytotic channels at the apex of the renal tubular epithelial cells (Fig. 3B).

The entire periphery of some plasmodia, and in limited peripheral regions of other plasmodia, comprised a distinct finely granular ectoplasm (2 to $10 \mu \mathrm{m}$ wide), within which were regions of intense pinocytotic activity (Fig. 2). The ectoplasm surrounded a complex heterogeneous endoplasm containing diverse organelles, cytoplasmic inclusions, and developing and mature spores (Fig. 4B). In other instances, a distinct ectoplasm was not seen, and the heterogeneous cytoplasm filled 


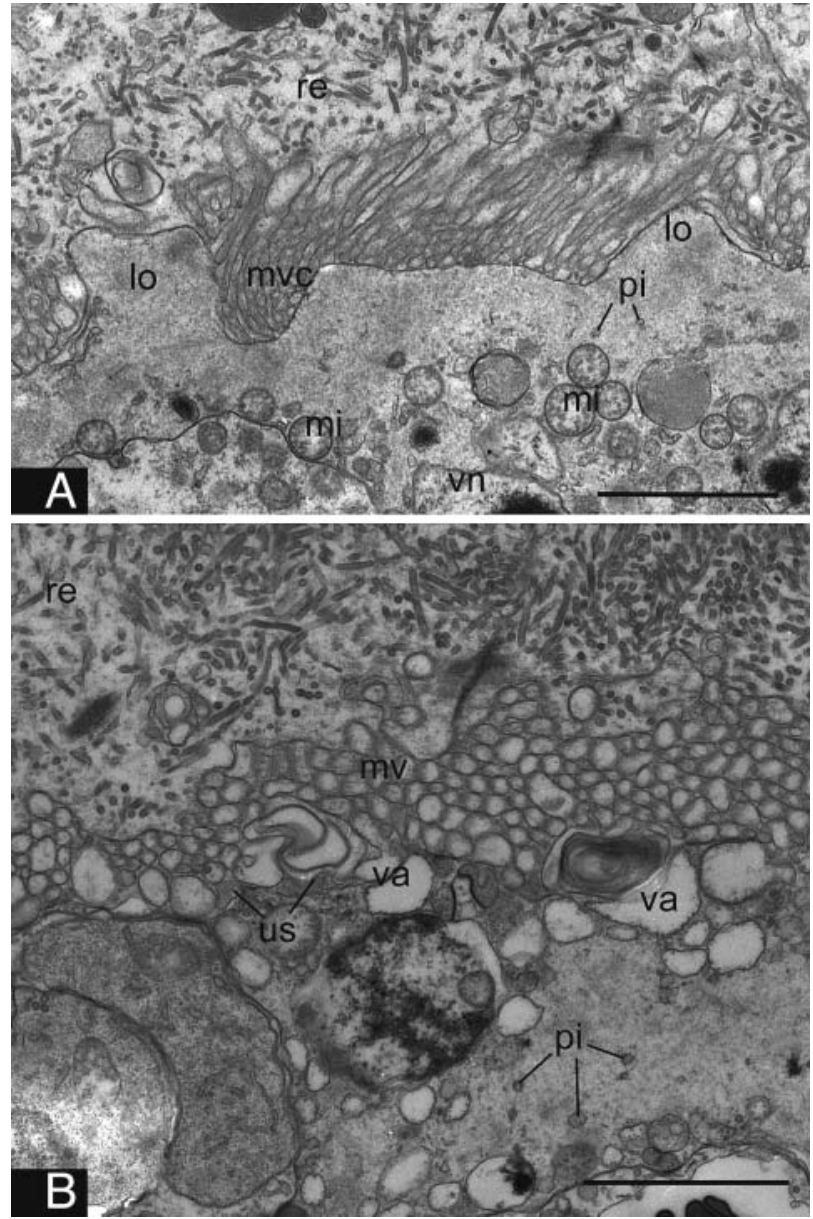

Fig. 3. Transmission electron micrograph of detail of hostparasite interface between plasmodia of Myxidium mackiei and the renal proximal convoluted tubule of the turtle Lissemys punctata andersonii. (A) Surface of a plasmodium with lobes (lo) penetrating into the host's renal epithelial cell (re), other regions lying against sheared and compressed microvilli (mvc), and pinocytosis in the ectoplasm (pi). Note also the mitochondria (mi) and vegetative nuclei (vn). (B) Surface of a plasmodium with a complex region of intermingled undulations of the parasite surface (us), microvilli (mv), and pinocytotic channels (pi), and vacuoles (va). Scale bars $=2 \mu \mathrm{m}$

the plasmodium, and some regions of the periphery of the plasmodia had large vacuoles (Fig. 4A).

The endoplasm (or cytoplasm in the case of plasmodia not divided into distinct ectoplasm and endoplasm) contained vegetative nuclei with irregularly clumped chromatin, numerous spherical mitochondria up to $0.5 \mu \mathrm{m}$ in diameter, and pinocytotic channels and vesicles (Fig. 2A,B). Cytoplasmic inclusions comprised regions of relatively homogenous cytoplasm (Figs. 2A \& 4B), electron-dense cytoplasm with foamy areas (Fig. 4B), and electron-lucent cytoplasm containing irregularly shaped membranous structures (Fig. 5). Sporogony was represented sequentially by various cell complexes: cell triplets (Fig. 2B, yellow), developing sporoblasts (Fig. 2B, red), and mature spore packets (Fig. 2B, green).

The cell triplets comprised an outer, amoeboid cell, enclosing 2 inner cells, and 1 nucleus or possibly 2 nuclei (Fig. 2B, yellow). All nuclei were approximately spherical, and contained an eccentric nucleolus, and sometimes also clumped chromatin. The outer and inner cells contained spherical mitochondria.

At an intermediate stage of sporogony, each sporoblast contained 2 developing spores (Fig. 2B, red). The polar capsule and its basal crescentic nucleus lay within a capsulogenic cell, and this in turn lay within a valvogenic cell, the latter recognized by its distinctive undulating surface (presumably the developing ribbed surface of the spore valve) (Fig. 2B). Spores developed in pairs within an outer cell (Fig. 2).

The cell complexes containing mature spores were readily recognizable in transverse section by their distinctive 'cogwheels within a figure 8' appearance (Figs. 2B, green, 5 \& 6). Two mature spores, each surrounded by a membrane-bound electron-lucent matrix, 0.7 to $1.4 \mu \mathrm{m}$ wide, lay together in an enclosing cell within the plasmodium (Figs. 5 \& 6). The cytoplasm of the enclosing cell was finely granular and contained small (up to $0.36 \mu \mathrm{m}$ diameter), spherical, dense mitochondria, a nucleus, membrane stacks, and vesicles and vacuoles (Fig. 6). In some mature cell complexes, the 2 adjacent individual electron-lucent matrices had fused (Fig. 6).

Other cell complexes were also present (Fig. 2B, blue), but the detail therein was insufficient for interpretation. Unfortunately, due to sub-optimal fixation (probably due to the initial formalin fixation), some membranes and internal spore structure were lost, and some structures were missing from the sections. These factors, coupled with the small numbers of infected turtles available to us, precluded documentation of the full series of events in sporogenesis of Myxidium mackiei.

\section{Myxidium mackiei: ultrastructure of the spore}

The spore valves had evenly ridged surfaces in transverse section, thus conferring longitudinal striations (Figs. 5 \& 6). In transverse section it was evident that the valves were not mirror images of each other, but were asymmetric, with one valve overlapping the other at the suture line. The number of ridges per overlapping valve ranged from 10 to 13 , and the number of ridges per overlapped valve ranged from 10 to 14 ( $\mathrm{n}=$ 12); the most common number of ridges in each valve was 10 or 12, and there was no consistent pattern of which valve had more ridges. In some spores, one or 

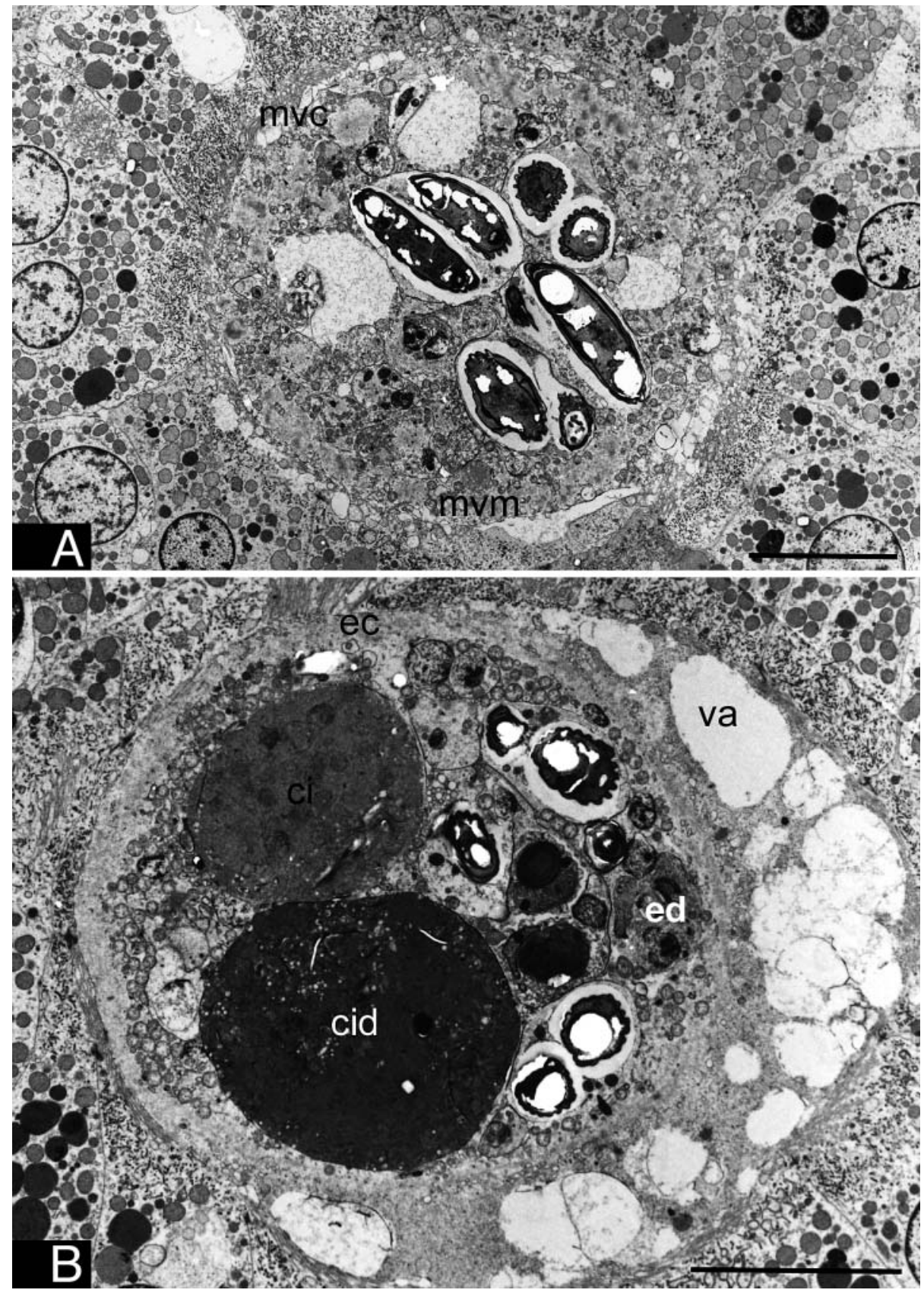

Fig. 4. Transmission electron micrographs of plasmodia of Myxidium mackiei in the renal proximal convoluted tubule of the turtle Lissemys punctata andersonii. (A) Plasmodium without distinct regions of ectoplasm and endoplasm. Some renal epithelial cells bear microvilli that are compressed (mvc), while other renal epithelial cells do not appear to bear microvilli (mvm). (B) Plasmodium with varying distinctions of ectoplasm (ec) and endoplasm (ed); in some peripheral regions there are numerous vacuoles (va). The plasmodial cytoplasm contains 2 large inclusions, one of which is relatively homogenous (ci), the other is relatively electron-dense with foamy areas (cid). Scale bars $=10 \mu \mathrm{m}$

both valves had a concentric ringed structure lying beneath the ridge adjacent to the suture.

The pairs of spores were slightly dimorphic when viewed in transverse section. Where both spores had valves with ridges, 1 spore was typically larger than the other (measured as maximal dimension from suture to suture); in other pairs, 1 spore had 2 valves with ridges, and 1 spore had only 1 valve with ridges. However, we were not able to determine if this apparent dimorphism was attributable to having different 


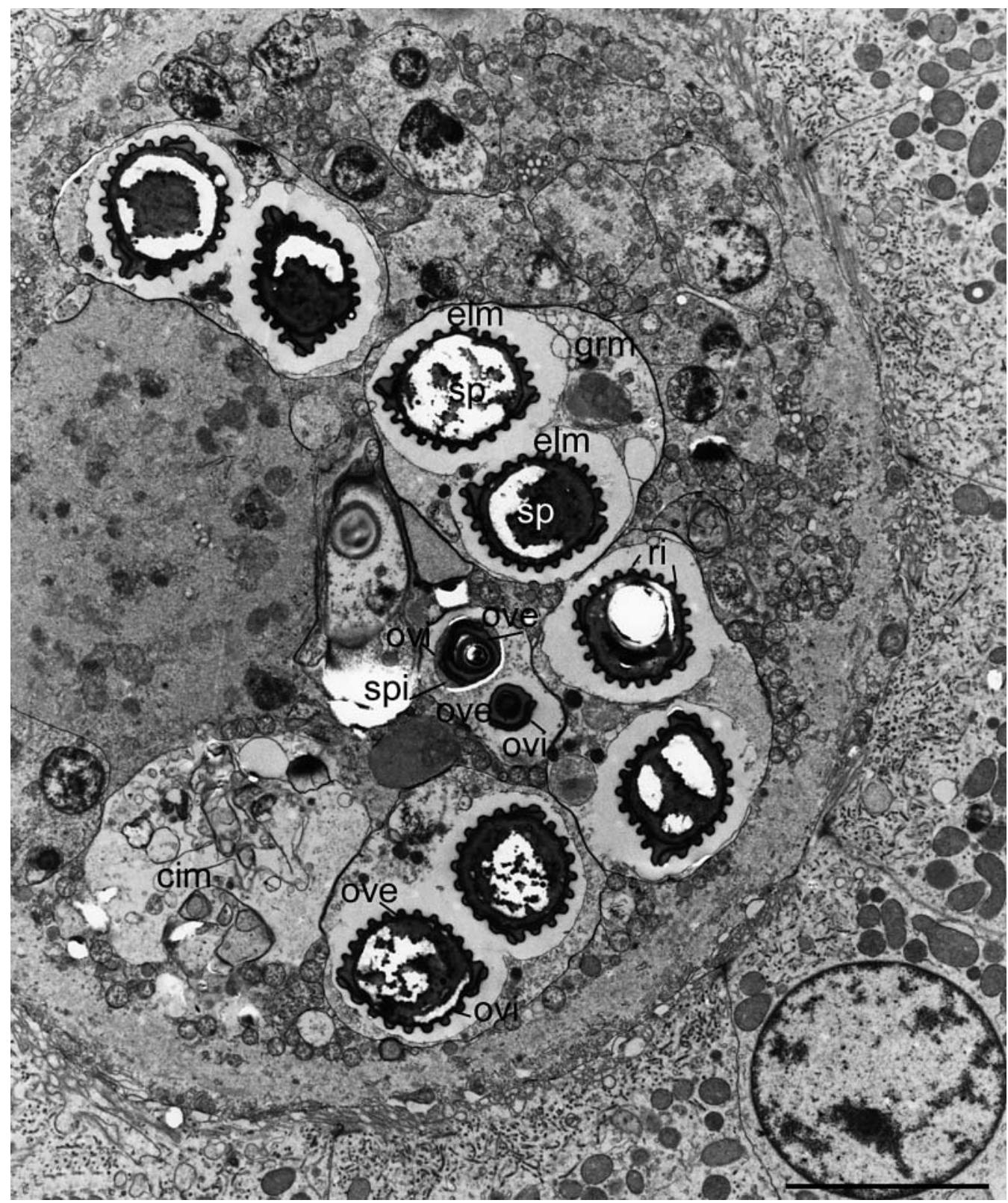

Fig. 5. Transmission electron micrograph of a plasmodium bearing mature spores of Myxidium mackiei in the renal proximal convoluted tubule of the turtle Lissemys punctata andersonii. Pairs of spores (sp), each individually surrounded by a membrane-bound electron-lucent matrix (elm), lay together in a surrounding cell having a finely granular matrix (grm). The numerous ridges on each valve (ri), conferring longitudinal striations, are clearly seen in this transverse section. In the immature spores (spi), the uneven development of the 2 valves is apparent, with one overlapping valve (ovi) enfolding the other overlapped (ove) valve. Note that the asymmetry of the valves is retained in the mature spores. The cytoplasm of this plasmodium has a large inclusion containing irregularly shaped membranous structures (cim). Scale bar $=5 \mu \mathrm{m}$

regions of the spores in section and/or different stages of maturity.

The wall of the pyriform polar capsule was $0.2 \mu \mathrm{m}$ thick (Fig. 7). Within the capsule was amorphous granular material and the polar filament, which was coiled rope-like upon itself, and then turned 4 to 5 times within the polar capsule (Fig. 7).

\section{Renal ultrastructure}

The site of infection was confirmed as the proximal convoluted tubule by the distinctive ultrastructure: a simple cuboidal to columnar epithelium, with an extensive brush border of microvilli on the luminal surface (Fig. 8). Just below the brush border lay the endo- 

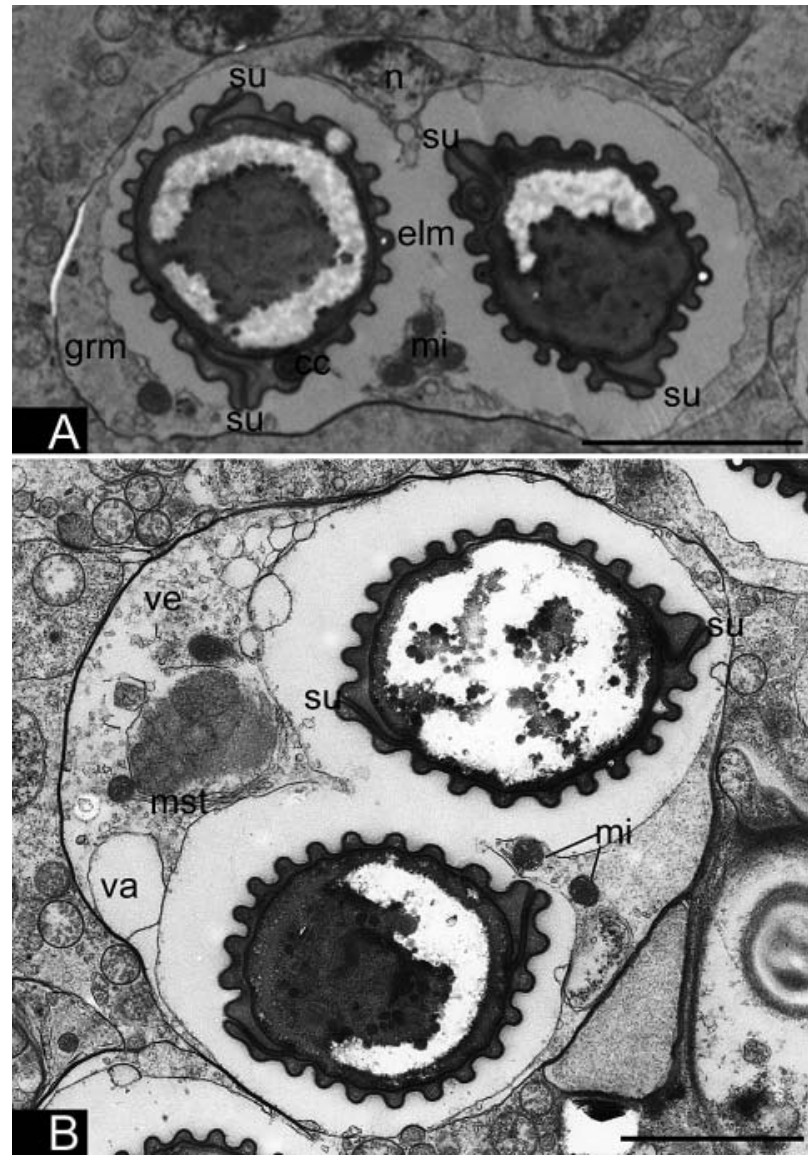

Fig. 6. Transmission electron micrograph of plasmodia bearing mature spores of Myxidium mackiei in the renal proximal convoluted tubule of the turtle Lissemys punctata andersonii. (A) A pair of spores, each of which has 1 valve with a concentric ringed structure (cc) adjacent to the sutural ridge (su). The spores lie in a membrane-bound electron-lucent matrix (elm), within a surrounding cell, which has a finely granular cytoplasm (grm) with small spherical, dense mitochondria (mi), and a nucleus (n). Scale bar $=5 \mu \mathrm{m}$. (B) A pair of spores without concentric ringed structures adjacent to the sutural ridge (su). The surrounding cell has small, spherical, dense mitochondria (mi), membrane stacks (mst), vesicles (ve), and vacuoles (va). Scale bar $=2 \mu \mathrm{m}$

cytotic region, with an extensive apical tubular network, evident as dark cylindrical branching bodies (Fig. 8B).

The cells of the proximal convoluted tubule had basolateral regions with few to no infoldings of the plasmalemma.

\section{Deposition of type material}

Histological sections stained with H\&E, Giemsa, GMS, PAS, and Ziehl-Neelsen acid-fast, with plas-

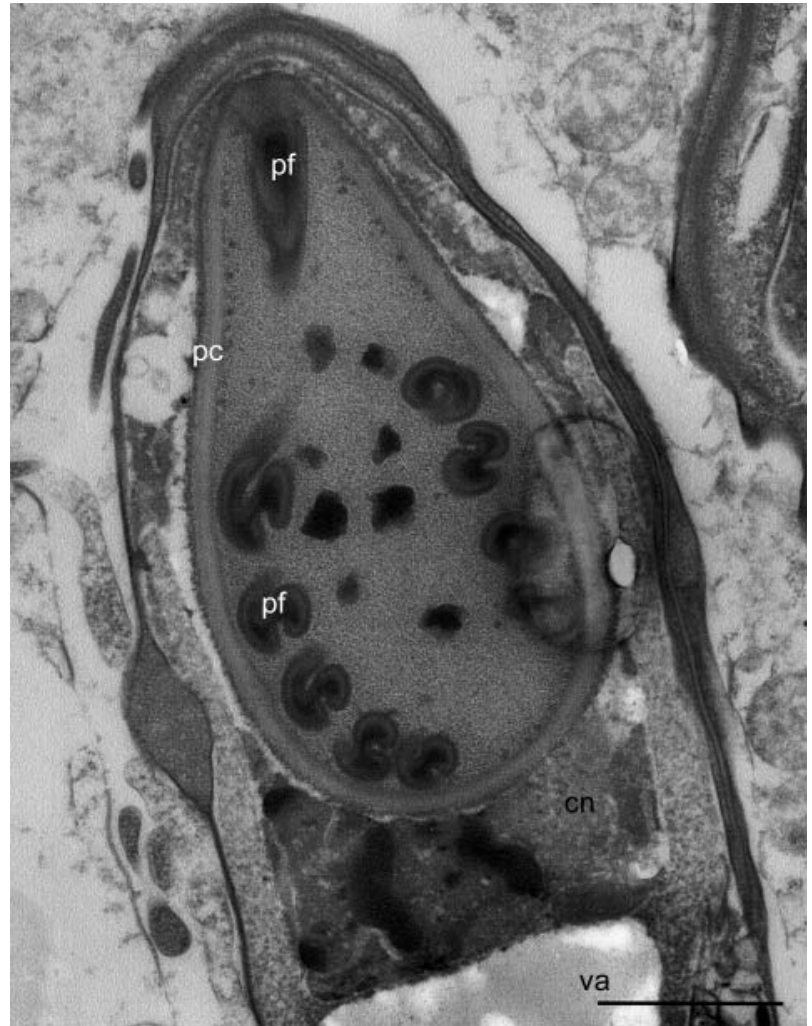

Fig. 7. Transmission electron micrograph of a mature spore of Myxidium mackiei in a plasmodium in the renal proximal convoluted tubule of the turtle Lissemys punctata andersonii. Longitudinal section through spore. The polar capsule (pc) is pyriform, and contains the polar filament (pf), which is coiled rope-like upon itself, and then turned 4 to 5 times. The remains of the capsulogenic nucleus ( $\mathrm{cn}$ ) can be seen at the base of the polar capsule, and below this is a large electronlucent structure, possibly the vacuole recognized in light microscopy (va). Scale bar $=1 \mu \mathrm{m}$

modia and spores of Myxidium mackiei, have been deposited in the US National Parasite Collection, USDA, ARS, BARC East, Building 1180, Beltsville, Maryland, 20705-2350, USA (Email: ehohberg@ anri.barc.usda.gov). Their accession numbers are USNPC \#095009.00, \#095010.00, \#095011.00, \#095012.00. Additional histological sections are in the collection of the Department of Comparative Medicine, Johns Hopkins University School of Medicine. Transmission electron microscopy samples are in the collection of the microscopy facility, Johns Hopkins University School of Medicine.

\section{DISCUSSION}

Both turtles had kidneys infected by the myxosporidian Myxidium mackiei, disseminated bacterial granu- 


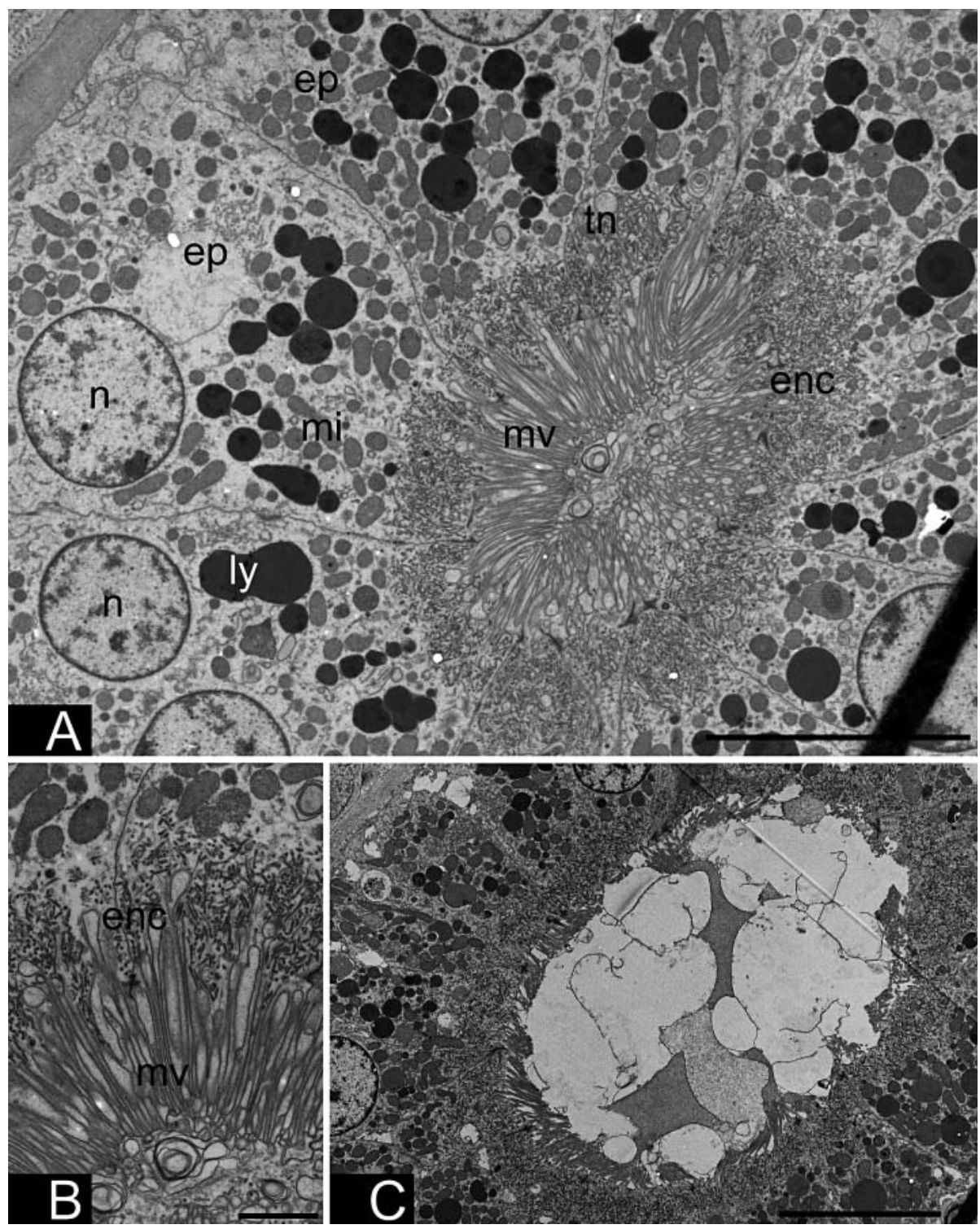

Fig. 8. Transmission electron micrograph of uninfected renal proximal convoluted tubules of the turtle Lissemys punctata andersonii. Transverse sections. (A) Tubule with a narrow lumen nearly filled with microvilli. The site was confirmed as proximal convoluted tubule by the distinctive architecture: a simple cuboidal/ columnar epithelium (ep), with an extensive brush border of microvilli on the luminal surface (mv); just below the brush border lie the endocytotic region (enc), and an extensive apical tubular network (tn). The cells also contain a spherical nucleus (n), abundant mitochondria (mi), and lysosomes (ly). The basolateral regions of the cells have few to no infoldings of the plasmalemma. (B) Enlargement of part of (A), showing intermingled microvilli $(\mathrm{mv})$, and at their bases, endocytotic regions (enc) of the renal epithelial cells. (C) Tubule with a wide lumen fringed by microvilli. Scale bars $(A, C)=10 \mu \mathrm{m} ;(B)=2 \mu \mathrm{m}$

lomas, and disseminated coccidia. Bacterial infection resulting in septicemia was considered to be the cause of death of Case 1, and cause of death could not be determined in Case 2. Although the parasitic infections were not considered to be significant factors in the mortality, they may have contributed to the morbidity of these individuals.

\section{Identification and characterization of spores of Myxidium mackiei}

The myxosporidian parasite was identified as a member of the genus Myxidium based on the fusiform spores with pointed ends, and the presence of 2 pyriform polar capsules, 1 at each end of the spore (Lom \& 
Table 1. Comparative morphometrics of Myxidium species observed in the present study with Myxidium species from related hosts (turtles), geographic localities (India), and tissues (kidney) (from Jayasari \& Hoffman 1982). Measurements ( $\mu m$ ) based on fresh material, unless indicated otherwise $\left({ }^{*}=\right.$ measurements on spores in histologic section.). B: bile; BD: bile duct; CT: connective tissue; G: gills; GB: gall bladder; K: kidney; LKT: lumen of kidney tubules; O: ovary; RT: renal tubule; U: ureters

\begin{tabular}{|c|c|c|c|c|c|c|c|c|}
\hline \multirow{2}{*}{ Species } & \multirow{2}{*}{ Place of origin } & \multirow{2}{*}{ Host } & \multirow[t]{2}{*}{ Site } & \multicolumn{2}{|c|}{ Spore } & \multicolumn{2}{|c|}{ Polar capsule } & \multirow[t]{2}{*}{ Striations } \\
\hline & & & & Length & Width & Length & Width & \\
\hline \multicolumn{9}{|l|}{ Turtles } \\
\hline M. americanum & N. America & Turtle & LKT & $15-16$ & $5.5-6.0$ & 4 & 3.5 & $8-10$ \\
\hline M. chelonarum & N. America & Turtle & $\mathrm{B}, \mathrm{GB}$ & 14 & 4 & $?$ & $?$ & $4-6$ \\
\hline M. danilewskyi & France & Turtle & $\mathrm{RT}$ & 12 & $3.0-4.0$ & $?$ & $?$ & $?$ \\
\hline M. mackiei* & India & Turtle & RT & 16 & 5 & $?$ & $?$ & + \\
\hline \multicolumn{9}{|l|}{ India } \\
\hline M. boddaerti & India & Fish & SI & 154.8 & 7.7 & 8.6 & 3.9 & - \\
\hline M. calcariferi & India & Fish & GB & $23-27$ & $6.0-8.0$ & 8.24 & 4.12 & + \\
\hline M. glossogobi & India & Fish & GB & 12.15 & $8.5-10.0$ & $3.1-4.1$ & $?$ & - \\
\hline M. heteropneustesi & India & Fish & GB & 14.42 & 6.18 & $4.12-6.18$ & 4.12 & + \\
\hline M. mackiei* & India & Turtle & RT & 16 & 5 & $?$ & $?$ & + \\
\hline M. melanocetum & India & Fish & $\mathrm{GB}, \mathrm{BD}$ & 19.8 & 4.5 & 6.7 & $?$ & $8-9$ \\
\hline \multicolumn{9}{|l|}{ Kidney } \\
\hline M. americanum & N. America & Turtle & LKT & $15.0-16.0$ & $5.5-6.0$ & 4 & 3.5 & $8-10$ \\
\hline M. barbatulae & France, USSR & Fish & K & $12.0-15.0$ & 6 & 5 & $2.5-3.0$ & + \\
\hline M. danilewskyi & France & Turtle & RT & 12 & $3.0-4.0$ & $?$ & $?$ & $?$ \\
\hline M. giardi & EU, USSR & Fish & $\mathrm{K}, \mathrm{G}$ & $9.0-10.0$ & $5-5.6$ & $?$ & $?$ & 9-11/valve \\
\hline M. illinoisense & N. America & Fish & K & $12.7-15.3$ & $7.6-9.3$ & $3.4-6.1$ & $?$ & 7-8/valve \\
\hline M. lentiforme & Japan & Fish & K & 19 & 5 & 4 & $?$ & - \\
\hline M. mackiei* & India & Turtle & $\mathrm{RT}$ & 16 & 5 & $?$ & $?$ & + \\
\hline M. macrocapsulare $\mathrm{E}$ & EU, USA, USSR & Fish & GB, $\mathrm{K}$ & $10.0-12.0$ & 6 & $3.0-4.0$ & $?$ & $6-8$ \\
\hline M. macrocapsulatum & Netherlands & Fish & K & 9.8-11.6 & $2.8-5.3$ & $2.8-4.5$ & $2.8-4.5$ & + \\
\hline M. minteri & N. America & Fish & $\mathrm{K}, \mathrm{RT}$ & $9.3-12.6$ & $6.0-7.0$ & $2.3-3.8$ & $?$ & + \\
\hline M. minteri* & & & & $8.0-9.6$ & $3.6-5.4$ & $1.8-3.6$ & $?$ & + \\
\hline M. rhodei & France, USSR & Fish & $\mathrm{K}, \mathrm{U}$ & $14-15$ & $3.8-4.0$ & 4.5 & $?$ & - \\
\hline M. rhomboideum & Netherlands & Fish & $\mathrm{K}$ & 7.7 & 6.4 & 3.5 & 2.1 & - \\
\hline M. stophilum & France & Fish & $\mathrm{K}, \mathrm{O}, \mathrm{CT}$ & 15 & $?$ & $?$ & $?$ & + \\
\hline M. uchiyamae & Japan & Fish & $\mathrm{K}$ & 13.5 & 6 & 6.5 & $?$ & + \\
\hline M. umbri & N. America & Fish & $\mathrm{K}, \mathrm{RT}$ & $12.0-14.4$ & $2.4-4.8$ & $3.0-4.8$ & 2.4 & - \\
\hline M. ventricosum & USSR & Fish & $\mathrm{RT}$ & $10.4-13.0$ & $6.5-7.0$ & $5.2-6.0$ & $3.3-4$ & - \\
\hline $\begin{array}{l}\text { Myxidium sp. Yasutake } \\
\text { and Wood, } 1957\end{array}$ & USA & Fish & RT & $14.5-16.4$ & $6.5-8.0$ & 3.8 & $?$ & - \\
\hline \multicolumn{9}{|l|}{ Present study } \\
\hline M. mackiei* & India & Turtle & RT, LKT & $12.9-17.6$ & $2.9-4.7$ & $3.4-4.1$ & $2.1-2.5$ & + \\
\hline
\end{tabular}

Dyková 1992). In order to determine species, we compared the morphometrics of the spores we observed with those of 22 Myxidium species described from related hosts, geographic localities, and tissues (Table 1).

Only 1 species of Myxidium has previously been described from a turtle in India (Jayasari \& Hoffman 1982), namely M. mackiei Bosanquet 1910, infecting the renal tubules of the closely related Indian softshelled turtle Trionyx gangeticus (like Lissemys punctata, also a member of the Family Trionychidae). The morphometrics of spores we observed in histological section (dimensions of spores and polar capsules, number and location of nuclei, and the presence of 2 vacuoles) of the Myxidium from our Indo-Gangetic flap-shelled turtles were consistent with those of M. mackiei (Bosanquet 1910) (Table 1). Fortuitously, the type description of $M$. mackiei was based on morphometrics of spores observed in histologic section. However, it is currently recommended that type descriptions of myxosporeans include morphometrics of fresh spores (Lom \& Arthur 1988). We observed striations on the spore valves, (a total of 20 to 28 per spore) via transmission electron microscopy. Striations were also reported for $M$. mackiei; however, their number was not reported, and it is not clear if the line drawing provided by Bosanquet (1910), which shows approximately 10 longitudinal striations, accurately represents the number of striations, or simply indicates the presence of striations. The presence of pairs of spores was 
clearly seen in our transmission electron micrographs, and was also noted for M. mackiei (Bosanquet 1910).

Five Myxidium species have been reported from fish in India, and of these, only $M$. calcariferi and $M$. heteropneuste have striated spores (Table 1). However, the spores we observed are much smaller than those of $M$. calcariferi, which are 23 to $27 \mu \mathrm{m}$ long and 6 to $8 \mu \mathrm{m}$ wide, even after taking into account the shrinkage in histologic section (assuming 10\%). In contrast, $M$. heteropneuste could be a possible match based on the length, but is much wider than our specimens (6.18 $\mu \mathrm{m}$ compared to 2.9-4.7 $\mu \mathrm{m}$ wide) and the polar capsules were much larger (4.18 to $6.18 \times 4.2$ compared to 3.4 to $4.1 \times 2.1$ to 2.4 ). Furthermore, in the turtles we studied, the site of infection was the renal tubules, whereas both $M$. calcariferi and M. heteropneuste infect the gall bladder.

Of the 17 Myxidium species reported from the kidney of their hosts (mostly from fish), only 8 have striated spores, namely $M$. americanum, $M$. barbatulae, M. giardi, M. illinoisense, M. mackiei, M. macrocapsulare, M. macrocapsulatum, and M. stophilum (Table 1). Myxidium spores from the Indo-Gangetic flap-shelled turtles are longer than those of $M$. giardi, $M$. illinoisense, M. macrocapsulare, and M. macrocapsulatum. The Myxidium spores from the flap-shelled turtles are similar in size to those of $M$. americanum, $M$. barbatulae, and M. stophilum, from North America, Eurasia, and France, respectively. However, the Myxidium spores from the Indo-gangetic flap-shelled turtles can be distinguished from each of these 3 species by the number of turns of the polar filament (4 to 5 in the former, only 3 in $M$. americanum), shape of the spore (regularly fusiform in the former, irregularly fusiform in $M$. barbatulae), and absence or presence of a medial compression of the valves (absent in the former, present in M. strophilium) (Jayasari \& Hoffman 1982).

\section{Characterization of the plasmodia of Myxidium mackiei}

We were able to make some limited comparisons of the plasmodia of the Myxidium from our Indo-Gangetic flap-shelled turtles and that of $M$. mackiei from the Indian soft-shelled turtle. In our light microscopy studies, we could not distinguish an ectoplasm, and according to Bosanquet (1910) for M. mackiei 'in the majority of cases no distinction between ectoplasm and endoplasm could be drawn'. Our ultrastructural studies did, however, reveal an ectoplasm, approximately 2 to $10 \mu \mathrm{m}$ wide, the narrowest regions of which would be difficult to visualize with light microscopy only. Numerous nuclei were present in the protoplasm of the parasite we observed and in M. mackiei as observed by Bosanquet (1910). We did not recognize the infrequent 'cuticle or cyst wall' around the plasmodia that Bosanquet (1910) reported for M. mackiei; however, it is possible that the narrow ectoplasm could have been interpreted as cuticle or cyst wall.

The plasmodium of Myxidium mackiei had a relatively smooth surface, and appeared to be retained against the renal epithelium by its physical presence/ pressure rather than by specialized microvilli, branching rhizoids, or other surface adornments that interdigitate with the tissue of the host. Specialized attachment modalities are known for some other coelozoic species such as $M$. giardi from the urinary bladder of the eel Anguilla mossambica (Paperna et al. 1987), M. lieberkuhni infecting the urinary bladder of the pike Esox lucius (Lom \& de Puytorac 1965b), Ortholinea fluviatilis and Zschokkella pleomorpha from the renal tubules of Tetraodon fluviatilis (Lom \& Dyková 1996), Sinuolinea tetraodini from the renal tubules of pufferfish Tetraodon palembangensis (El-Matbouli \& Hoffmann 1994), and Sphaeromyxa sabrazesi, Sphaeromyxa sp. and Zschokkella russeli from the gall bladder of marine fish (Stehr \& Whitaker 1986).

The pinocytotic channels invaginating the surface of the plasmodium of Myxidium mackiei, and the pinocytotic vesicles in the ectoplasm, provided for nutrient uptake from the host. Similar structures are known from many other plasmodia, including species of Henneguya, Kudoa, Myxobolus, and Thelohanellus (Stehr \& Whitaker 1986). In contrast, nutrient uptake in some coelozoic myxosporean plasmodia, including Myxidium lieberkuehni in the urinary bladder of Esox lucius, is believed to occur principally through surface absorption through microvilli (Lom \& de Puytorac 1965b).

The generative cells of Myxidium mackiei had a smooth surface, contrasting with the pseudopodia adorning the generative cells of $M$. lieberkuehni and M. rhodei (Lom \& de Puytorac 1965a, Dykova et al. 1987).

Most of the organelles and structures within the cytoplasm of the plasmodium were readily recognized, and the combination thereof may be a helpful speciesspecific descriptor, as is known for the histozoic species Kudoa thrysites and $K$. paniformis infecting the muscle of marine fish (Stehr \& Whitaker 1986).

We suggest that the large electron-dense inclusions with foamy areas, reaching $50 \mu \mathrm{m}$ in diameter, in the cytoplasm of the plasmodium of Myxidium mackiei were the inclusions that appeared golden in histological sections stained with hematoxylin and eosin (H\&E). Since these inclusions were negative with Hall's bilirubin stain, Prussian blue stain, and periodic acid-Schiff (PAS) we can exclude the possibility that these inclusions were bile, iron, or lipofuscin. Contradictory results were obtained for ceroid; positive (pink) staining was present with Ziehl-Neelsen acid-fast stain; 
however, these inclusions did not auto-fluoresce. The size and staining properties of the golden inclusions in the plasmodia were the same as those of the golden inclusions in the interstitium of the kidney, suggesting that the same structures occurred in the parasite and the host. It is possible that the inclusions are akin to the yellow pigment bodies (secondary lysosomes) described from the hagfish Myxine glutinosa by Hickman \& Trump (1969) and Holmgren (1950), containing a substance which may be similar to lipofuscin. The latter author asserts that the yellow pigment bodies are excreted into the lumen of the tubule. Even if this were the case in the turtles we examined, this is unlikely to account for the presence of the bodies in the plasmodium, since they are considerably larger (reaching up to $50 \mu \mathrm{m})$ than could be taken in by pinocytosis, which was the only method of obtaining nutrients that we observed in the plasmodium. We therefore suggest that the golden inclusions develop within the plasmodium de novo.

\section{Parasite-host interaction}

The plasmodia of Myxidium mackiei occluded the lumen of 5 to $10 \%$ of the renal tubules, and ultrastructural studies showed that the plasmodia modified the luminal surface of the hosts' renal epithelial cells via shearing and compression of the microvilli, and in some cases microvilli appeared to be effaced. Compression of microvilli at the plasmodia surface is also known for Ortholinea fluviatilis in renal tubules of Tetraodon fluviatilis (Lom \& Dyková 1996). Beyond these findings, we were not able to detect pathology induced by the parasite, consistent with the observation in the type description of $M$. mackiei from $T$. gangeticus that 'the parasites did not appear to incite any reaction in the tissue of the host, the animal's health being unaffected' (Bosanquet 1910). The lack of apparent effects on the tubules during the sporogonic stages of development is also consistent with other renal myxosporeans, such as Sphaerospora species, that infect fishes (El-Matbouli \& Hoffmann 1994).

Although proliferative inflammation is the principal defense mechanism against myxosporean infections in fish, and is initiated with plasmodia containing mature spores (Lom \& Dyková 1995), this host response was not seen in either of our infected turtles. The mutually tolerant host-parasite relationships between the turtles and Myxidium mackiei may be indicative of a long period of host-parasite co-evolution. Such benign infections are consistent with the case for the majority of myxosporean infections, and only relatively few species are known to cause serious or fatal infections (Lom \& Dyková 1995).
Among the better known species of Myxidium infecting the excretory system of fishes, there is a diversity of host response to infection (Lom \& Dyková 1992, 1995). In M. giardi infecting eels, Anguilla spp., the parasite induces focal granulomatous reactions in various organs, and serious changes in tubules and glomeruli of the kidney, with elvers developing dropsy and suffering mass mortality. In M. lieberkuehni infecting Esox lucius, epithelium of tubules and connecting ducts may have dystrophic changes, and destruction of the renal corpuscle stage involves granulomatous inflammation; both changes are considered to be of minor significance. In M. minteri in salmonids, renal tubular degeneration is seen. Among the more pathogenic infections is M. rhodei in the kidney of roach Rutilus rutilus in which there is hypertrophy of the renal corpuscles, atrophy of the renal parenchyma, decrease in the number of glomeruli, atrophy of surrounding tissue, and granulomatous inflammatory changes in the interstitium (Dyková et al. 1987).

Although we only observed plasmodia in the tubules of the turtles, we expect that the preceding extrasporogonic stages would occur intracellularly in the epithelial cells of the renal tubules, and then pass into the lumen.

\section{Life cycle}

Among the most significant advances in understanding myxosporean life cycles has been the demonstration of some life cycles requiring 2 hosts, with the myxosporean stage infecting fish and the actinosporean stage infecting invertebrates, such as annelid worms and bryozoans (Kent et al. 2001). Life cycles have been established for about 25 of the 1250 myxosporean species described, with the research being focused on parasites of commercially important freshwater, anadromous or catadromous fish (Diamant 1997, Kent et al. 2001). To the best of our knowledge, the life cycles of myxosporeans from turtles are not known.

However, we can make some inferences about possible life cycles of the Myxidium species in the renal tubules of these turtles, based on what is known for other Myxidium species infecting fish, and other myxosporeans infecting the kidney. An indirect life cycle has been demonstrated for Myxidium giardi infecting the kidney and gills of the European eel Anguilla anguilla with transmission via an aurantiactinomyxon in the oligochaete Tubifex tubifex (Benajiba \& Marques 1993). In contrast, a direct life cycle has been demonstrated for $M$. leei infecting the intestine of sea bream Sparus aurata (Diamant 1997). $M$. leei can be transmitted directly from fish to fish by 
ingestion of fresh fecal and mucous matter, of gut mucosa fragments (as demonstrated in a series of experiments with cohabitation) of effluent, and by feeding upon pieces of freshly dissected infected gut (Diamant 1997).

Although we did not have an opportunity to investigate the life cycle of Myxidium mackiei in the turtle, we consider that either an indirect or a direct life cycle is possible. An indirect life cycle could involve acquisition of infection through injection of a sporoplasm from an actinosporean into the skin, (as occurs in Myxobolus cerebralis infecting salmonids; El-Matbouli \& Hoffmann 1989), since the skin of the species of turtle we studied is soft, rather than covered with hard scales. An alternative indirect life cycle could involve ingestion of an infected host, as is known to occur for acquisition of $M$. cerebralis from ingestion of infected Tubifex tubifex (Wolf \& Markiw 1984). For a direct life cycle, transmission could occur via ingestion.

\section{Pathology not associated with Myxidium mackiei}

The cause of the bacterial disease(s), that culminated in disseminated granulomas in both individuals, remains unknown. It is likely that the initial invading bacteria were attacked by heterophils, and that dense solid pus was produced (probably due to the lack of proteases within the heterophils; Montali 1988). In contrast, in mammals, neutrophils would be involved, and liquefied pus would be produced. The heterophils probably underwent necrosis, to become the amorphous debris in the center of the granulomas, further inciting the macrophage response, and eventually becoming surrounded by multi-nucleate giant cells. Lesions having such development can rapidly progress to granulomas within 1 wk in warm-blooded birds; however, the process may take longer in cold-blooded reptiles, since it is dependent on the animal's body temperature (Montali 1988). Formation of granulomas is the predominant response to microorganism infection in reptiles and birds, which have fewer available responses to microorganisms than do mammals (Montali 1988). Fibrosis was present in only a few lesions in the turtles, which may indicate that most of the lesions (without fibrosis) were relatively recent, since in chronic lesions, dense fibrous connective tissue capsules frequently surround multi-nucleate giant cell granulomas (Frye 1991).

Tubular mineralization of the kidney seen in Case 1 is often found due to chronic disease that may no longer be present, or due to a persistent insult. Case 1 also displayed serous atrophy within the adipose tissue, as is commonly seen when animals are inappetant.

\section{Coccidian infection}

The sporulated coccidian oocysts present in the lung and liver were tentatively identified as Eimeria based on their appearance in histological section; the parasites were keyed out to this genus using the identification key in the most recent edition of the Illustrated Guide to the Protozoa (Perkins et al. 2000). We report our identification as tentative, since we were only able to examine parasites in histological section; detailed examination of whole fresh preparations may have revealed additional morphological features which would lead to identification to another genus. Although Perkins et al. (2000) report only the genus Eimeria as having thin-walled oocysts, containing 4 sporocysts, each of which contains 2 sporozoites, some other authors also recognize the genus Goussia, which is similar, but has valves united by a suture. In addition to the minor structural differences, Goussia differs in some biological properties from Eimeria, including the requirement, in the former, of an invertebrate intermediate host.

\section{Kidney ultrastructure}

The ultrastructure of the chelonian kidney has been rarely reported (Meseguer et al. 1987), in contrast to that of many orders of vertebrates. In the IndoGangetic flap-shelled turtle, the cells of the proximal convoluted tubule had baso-lateral regions with few to no infoldings of the plasmalemma; thus, there was little interdigitation of adjacent cells. This is in contrast to the extensive infoldings of the lateral or basolateral plasmalemma in the fish and mammalian proximal tubule cell (Koushanpour \& Kriz 1986, Hentschel \& Elger 1987). A distinctive feature of the turtle proximal tubule cells we observed was the extensive apical tubular network lying just beneath the brush border. From other animals, a variety of similar organelles have been reported in this location, including tubular and vesicular membranes (Hentschel \& Elger 1987), apical tubules (Hickman \& Trump 1969), a tubular system (Hentschel \& Elger 1987), and wavy filament bundles (Meseguer et al. 1987). The uniform width of the tubular network and the elaborate branching we observed were very similar to the $0.1 \mu \mathrm{m}$ diameter tubular membrane system of the lamprey Lampetra fluviatilis, which is connected to the lateral and basal cell membranes via numerous small openings, and has luminal sides of the membranes coated with an electron dense material arranged helically in parallel rows - which appears to confer some rigidity to the network (Hentschel \& Elger 1987). A similar tubular system is also known from English sole Porophrys 
vetulus (Trump \& Jones 1977). The appearance of the tubular network in the Indo-Gangetic flap-shelled turtle was not consistent with vesicular membranes arising from apical invaginations of the plasma membrane.

Acknowledgements. We warmly thank Drs. E. Bronson, M. Denver and M. Cranfield of the Baltimore Zoo for submitting these cases, Ms. P. Wilcox of The Johns Hopkins University School of Medicine for preparing histologic sections, Mr. M. Delanoy of The Johns Hopkins University School of Medicine microscope facility for transmission electron microscopy (TEM) expertise, Dr. A. Kincaid of Antech Diagnostics and Dr. J. L. Mankowski of The Johns Hopkins University School of Medicine for the insightful discussions of pathology associated with these turtles (A. Kincaid and J. L. Mankowski) and critical review of the manuscript (J. L. Mankowski), Dr. R. Reimschuessel of the US Food and Drug Administration for help with renal ultrastructure, and Ms. S. Williamson for her expertise with computer-generated figures. Portions of this work were presented as a poster and as Abstract \#41 in the Proceedings for the Combined 53rd and 37th Annual Meetings of the American College of Veterinary Pathologists and the American Society for Veterinary Clinical Pathologists, New Orleans, LA, Dec 8-11, 2002. The work was funded by NRSA RR07002 (K.L.H.).

\section{LITERATURE CITED}

Benajiba MH, Marques A (1993) The alternation of actinosporean and myxosporidian sporal forms in the development of Myxidium giardi (parasite of Anguilla anguilla) through oligochaetes. Bull Eur Assoc Fish Pathol 13: 100-103

Bosanquet WC (1910) Brief notes on two Myxosporidan organisms (Pleistophora hippoglossoides, n.sp. and Myxidium mackiei n. sp.). Zool An 35:434-438

Diamant A (1997) Fish-to-fish transmission of a marine myxosporean. Dis Aquat Org 30:99-105

Dyková I, Lom J, Grupcheva G (1987) Pathogenicity and some structural features of Myxidium rhodei (Myxozoa: Myxosporea) from the kidney of the roach Rutilus rutilus. Dis Aquat Org 2:109-115

El-Matbouli M, Hoffmann RW (1989) Experimental transmission of two Myxobolus spp. developing bisporogony via tubificid worms. Parasitol Res 75:461-464

El-Matbouli M, Hoffmann RW (1994) Sinuolinea tetraodoni n.sp., a myxosporean parasite of freshwater pufferfish Tetraodon palembangensis from Southeast Asia - light and electron microscope observations. Dis Aquat Org 19:47-54

Frye FL (1991) Reptile care; an atlas of diseases and treatments, Vol 2. TFH Publications, Neptune City, NJ

Gardiner CH, Fayer R, Dubey JP (1988) An atlas of protozoan parasites in animal tissues. Agriculture Handbook No. 651. US Department of Agriculture, Washington, DC

Hentschel H, Elger M (1987) The distal nephon in the kidney of fishes. Adv Anat Embryol Cell Biol No. 108. SpringerVerlag, Berlin

Hickman CP, Trump BF (1969) The kidney. In: Hoar WS, Randall, DJ (eds) Fish physiology, Vol 1. Excretion, ionic

Editorial responsibility: Peernel Zwart,

Utrecht, The Netherlands regulation, and metabolism. Academic Press, New York, p 91-239

Holmgren N (1950) On the pronephros and the blood in Myxine glutinosa. Acta Zool 31:233-348

Jayasari M, Hoffman GL (1982) Review of Myxidium (Protozoa: Myxozoa: Myxosporea). Protozool Abst 6:61-91

Johnson CA (1969a) Myxidium chelonarum n. sp. (Cnidospora: Myxidiidae) from various North American turtles. Assoc SE Biol Bull 16:56

Johnson CA (1969b) A redescription of M. chelonarum Johnson, 1969 (Cnidospora: Myxidiidae) from various North American turtles. J Protozool 16:700-702

Kent ML, Andree KB, Bartholomew JL, El-Matbouli M and 12 others (2001) Recent advances in our knowledge of the Myxozoa. J Eukaryot Microbiol 48:395-413

Koushanpour E, Kriz W (1986) Renal physiology. SpringerVerlag, New York

Kudo RR (1919) Studies on Myxosporidia: a synopsis of genera and species. Ill Biol Monogr 5:1-265

Lom J, Arthur JR (1988) A guideline for the preparation of species descriptions in Myxosporea. J Fish Dis 12:151-156

Lom J, de Puytorac P (1965a) Observations sur l'ultrastructure des trophozoites de myxosporidies. CR Hebd Seanc Acad Sci Paris 260:2588-2590

Lom J, de Puytorac P (1965b) Studies on the myxosporidian ultrastructure and polar capsule development. Protistologica 1:53-65

Lom J, Dyková I (1992) Protozoan parasites of fishes. Elsevier, Amsterdam

Lom J, Dyková I (1995) Myxosporea (Phylum Myxozoa). In: Woo PTK (ed) Fish diseases and disorders, Vol 1. Protozoan and metazoan infections. $\mathrm{CAB}$ International, Wallingford, Oxon, p 97-148

Lom J, Dyková I (1996) Notes on the ultrastructure of two myxosporean (Myxozoa) species, Zschokkella pleomorpha and Ortholinea fluviatilis. Folia Parasitol 43:189-202

Meseguer J, Garcia Ayala A, Agulleiro B (1987) Ultrastructure of the nephron of freshwater turtles, Pseudemys scripta elegans, Mauremys caspica. Cell Tissue Res 248: 381-391

Montali RJ (1988) Comparative pathology of inflammation in the higher vertebrates (reptiles, birds, and mammals). J Comp Pathol 99:1-26

Paperna I, Hartley AH, Cross RHM (1987) Ultrastructural studies on the plasmodium of Myxidium giardi (Myxosporea) and its attachment to the epithelium of the urinary bladder. Int J Parasitol 17:813-819

Perkins FO, Barta JR, Clopton RE, Peirce MA, Upton SJ (2000) Phylum Apicomplexa Levine, 1970. In: Lee JJ, Leedale GF, Bradbury P (eds) An illustrated guide to the protozoa, 2nd edn. Society of Protozoologists, Lawrence, KS, p 190-369

Stehr C, Whitaker DJ (1986) Host-parasite interaction of the myxosporeans Kudoa paniformis Kabata \& Whitaker 1981 and Kudoa thyrsites (Gilchrist 1924) in the muscle of Pacific whiting, Merluccius productus (Ayres): an ultrastructural study. J Fish Dis 9:505-517

Trump BF, Jones RT (1977) Correlation of structure and active transport in the teleost nephron. J Exp Zool 199:365-382

Wolf K, Markiw ME (1984) Biology contravenes taxonomy in the Myxozoa: new discoveries show alteration of invertebrate and vertebrate hosts. Science 225:1449-1452

Submitted: January 18, 2004; Accepted: August 3, 2004

Proofs received from author(s): February 16, 2005 